\title{
EFFECT OF HCV DIRECT ANTIVIRAL AGENTS ON PORTAL CIRCULATION HEMODYNAMICS IN CIRRHOTIC PATIENTS
}

\author{
By
Mostafa Abd El-Hamid Selima, Nader Farid Mostafa, Galal Abd El- Hameed Abou-Farrag, and Mohamed Abbas Deif* \\ Infectious diseases, Gastroenterology and Hepatology Department, AlAzhar Faculty of \\ Medicine, AlAzhar University, Cairo, Egypt \\ *Diagnostic and Interventional Radiology Department, National Liver Institute (NLI), \\ Menoufia University, Shebin El-Kom, Menoufia, Egypt \\ Corresponding author: Mostafa Abd El-Hamid Selima
}

Mobil: 01008469283, E-mail: mostselima@gmail.com

\begin{abstract}
Background: Eradication of hepatitis $\mathrm{C}$ virus (HCV) infection using direct-acting antiviral Agents (DAAs) nowadays is almost always hopeful. Sustained virological response (SVR) has been documented in more than $90 \%$ of cases. This prevents more fibrosis and precludes the progression of portal hypertension ( $\mathrm{PH})$.

Objective: detect the effect of HCV Direct Antiviral Agents on portal circulation hemodynamics.

Patients and methods: This prospective descriptive study that was conducted on $70 \mathrm{HCV}$ infected patients with liver stiffness measurement $(\mathrm{LVM}) \geq 14.0 \mathrm{Kpa}$ and underwent treatment with DAAs therapeutic regimens. They were subjected to pre-treatment, end of treatment (EOT) and 1 year after EOT laboratory, transient elastography (TE) and Doppler assessment at Gastroenterology, Hepatology and Infectious diseases Department, Al-Hussien University Hospital, Cairo and National Liver Institute, Menoufia, Egypt in the period from May 2018 to December 2019.

Results: Liver function tests including serum bilirubin, albumin, international ratio (INR), alanine transaminase (ALT) and aspartate transaminase (AST) were improved with variable significant values at EOT and 1 year after treatment, while hemoglobin and platelet count decreased. LVM values decreased significantly at the end of treatment $(\mathrm{P}<0.001)$. Doppler parameters including portal vein diameter, portal vein velocity $(\mathrm{PVV})$, congestion index of portal vein $(\mathrm{CI})$ and liver vascular index $(\mathrm{P}$ value $<0.001)$ were improved significantly 1year after EOT. Also, resistive index of hepatic artery (HARI) $(\mathrm{P}$ value $=0.001$ ) significantly improved at the same point of time.
\end{abstract}

Conclusion: Doppler portal hypertensive parameters, as a marker of portal hypertension, improved in parallel with the improvement in LVM, ALT and AST values after viral eradication.

Key words: Portal Hemodynamics, HCV eradication, Liver Stiffness, Direct acting antiviral, Portal vein Doppler parameters.

\section{INTRODUCTION}

Chronic hepatitis $\mathrm{C}$ virus (HCV) infection affects about 80 million people worldwide (Gower et al., 2014). Ongoing hepatic inflammation may lead to liver fibrosis, cirrhosis and ultimately portal hypertension which may be complicated by ascites, variceal bleeding and hepatic encephalopathy. Moreover, patients are at 
considerable risk for the development of hepatocellular carcinoma (HCC) (Tsochatzis et al., 2014).

The interferon (IFN) based therapies were limited in patients with advanced liver disease due to adverse events in addition to its modest efficacy (Reiberger et al., 2011 and Hézode et al., 2014). In contrast, novel IFN free regimens are highly effective and generally well tolerated (Mandorfer et al., 2015). Touting rates of sustained virologic response (SVR), which dense the cure of chronic hepatitis C (CHC), exceeding 95\% (Charlton et al., 2015 and Manns et al., 2016) and the focus of attention has now shifted to the regression of $\mathrm{HCV}$ induced liver fibrosis, cirrhosis, and portal hypertension after treatment (Pinzani et al., 2015).

In addition, hemodynamic changes in advanced cirrhosis were found to associate with the development of hepatorenal syndrome (Møller and Henriksen,2010) Thus, it is postulated that hemodynamic parameters may provide unique information on the prognosis of cirrhotic patients (Hsieh et al., 2018). Many studies showed significant correlation between severity of liver dysfunction or Child-Pugh score (Achim et al., 2016 and Ahmed \& Medhat, 2019) and portal circulation hemodynamics, others showed correlation between liver function tests and portal circulation hemodynamics (Akhter et al., 2012, Mahmoud et al., 2014, Mahmoud et al., 2017 and Elsayed et al., 2019).

Multiple parameters, which could be measured with Doppler ultrasound, are reported to be altered with the progression of hepatic fibrosis and are considered as markers of $\mathrm{PH}$ such as portal vein velocity (PVV), portal vein flow rate (PVF) and Congestion Index (CI) (Mahmoud et al., 2014).

The aim of the study was to assess the effect of HCV eradication with DAAs on portal circulation Doppler parameters and degree of liver fibrosis one year after EOT.

\section{MATERIALS AND METHODS}

This Prospective descriptive study was carried out on $70 \mathrm{HCV}$ infected patients, aged 55.71 \pm 8.97 years old, with definite liver fibrosis (F4: $\geq 12.5 \mathrm{Kpa}$ ) achieved SVR12 on follow up with laboratory, transient elastography (TE) and ultrasonography examination before and after HCV treatment with DAAs containing Interferon (INF) free therapeutic regimens at Gastroenterology, Hepatology and Infectious diseases Department, Al-Hussien University Hospital, Cairo and National Liver Institute, Menoufia, Egypt in the period from May 2018 to December 2019.

Patients with HCV infection was detected depending on both $\mathrm{HCV} \mathrm{Ab}$ and HCV RNA PCR $\geq 15 \mathrm{IU} / \mathrm{L}$. The inclusion criteria included the range of patients' age from 18 up to 65 years old and had chronic infection with $\mathrm{HCV}$, with detectable HCV RNA. Those patients had Child-Pugh score A. For the baseline assessment, all patients were subjected to Complete history taking, and full Clinical Examination. Blood samples were collected from patients and submitted to complete blood count (CBC), alanine aminotransferase (ALT), aspartate aminotransferase (AST), serum albumin (ALB), total bilirubin, direct bilirubin, 
prothrombin time and INR, serum creatinine, pregnancy test (for females at fertility period), Alpha Feto Protein (AFP), Fasting Blood Glucose (FBG) level and hemoglobin A1c, HBsAg (Hepatitis B surface antigen). Baseline measurement of liver stiffness is performed in addition to liver ultrasonogrophy including Doppler of portal vein and hepatic artery to assess portal vein (PV) diameter, cross-sectional area, mean PV velocity (PVV), PV flow volume (PVF), congestion index of portal vein $(\mathrm{CI})$, hepatic artery pulsitility index (HAPI), hepatic artery resistive index (HARI) and liver vascular index (LVI). It was done with Color duplex ultrasound machine (logiQ E10) with curved probe with multi-frequency convex transducer. The examination was carried out on patients under fasting and in a supine position for 15 minutes. The Doppler sample was positioned in the middle of the lumen. The following variables were calculated: (1) Portal vein diameter ( $\mathrm{mm}$ ): The portal vein was measured at the hepatic hilum, proximal to the bifurcation. (2) Cross-sectional area of the portal vein $(\mathrm{cm} 2)$ : Cross sectional area $=(\pi \times$ diameter^2)/4. (3) PVV ( $\left.{ }^{\wedge} / \mathrm{sec}\right)$ : Hemodynamic measurements were done during a brief apnea after a small breath. The insonation angle between the vessel and Doppler beam was $<600$ for accuracy (Achim et al., 2016). (4) PVF $(\mathrm{mL} / \mathrm{sec})=$ $\left[\left(\pi \times\right.\right.$ diameter $\left.\left.^{\wedge} 2\right) / 4\right] \times$ mean velocity $\times 60$ (Kayacetin et al., 2004). (5) HAPI = (Peak systolic velocity - end diastolic velocity)/ (Mean velocity). (6) HARI $=($ Peak systolic velocity - end diastolic velocity)/ (Peak systolic velocity) (Ahmed and Medhat 2019). (7) CI (cm x sec) $=$ (crosssectional area of the portal vein)/ (mean portal vein velocity) (Elsayed et al., 2019). (8) LVI = (Portal vein velocity)/HAPI (Achim et al., 2016).

FibroScan, using echosens FibroScan compact 530 Machine, was performed on the right lobe of the liver by same clinician. A total of 10 measurements, expressed in Kpa, were obtained at each assessment and the median was determined. LSM score range from 2.50 to $75 \mathrm{Kpa}$ (Soresi et al., 2014). LSM values were used to estimate the METAVIR fibrosis stage as follows: F0-F1: 2.5 to 6.9 $\mathrm{Kpa} / \mathrm{F} 2: 7.0$ to $9.4 \mathrm{Kpa} / \mathrm{F} 3: 9.5$ to 12.4 Kpa/ F4: $\geq 12.5$ Kpa. Cirrhosis was defined as an LS score of $12.5 \mathrm{Kpa}$ or more (Castéra et al., 2005).

The treatment protocols were applied for all patients according to National Egyptian protocol: Sofosbuvir/ Dacltasvir, Sofosbuvir/ Simprevir, Sofosbuvir/ Dacltasvir/ Ribavirin and Sofosbuvir/ Simprevir/ Ribavirin for 5 (7.1\%), 8 (11.4\%), 53 (75.8\%), $9(12.9 \%)$ and 4 $(5.7 \%)$ patients respectively. 59 patients $(84.3 \%)$ were treated for 12 weeks and 11 patients $(15.7 \%)$ for 24 weeks.

All patients were submitted to the following investigations immediately at the end point of treatment (EOT) with routine clinical examination, Laboratory investigation: $\mathrm{CBC}$, ALT, AST, total bilirubin, direct bilirubin, serum albumin, INR and Serum creatinine, serum real time HCV-RNA PCR. The latter was the only at week 12 after EOT for assessment of SVR12.

All patients were submitted to the following investigations 1year after EOT with Routine clinical examination, laboratory investigation: $\mathrm{CBC}, \mathrm{ALT}$, AST, total bilirubin, serum albumin, INR 
and serum creatinine, serum real time HCV-RNA PCR, TE, Doppler assessment of values of portal vein and hepatic artery parameters. We carried out different correlations between the hemodynamic variables obtained from the Doppler examination, the liver stiffness and laboratory findings.

The patients were excluded from participating in the study if they had HIV or hepatitis B co-infection, history of major organ transplantation, or recent drug or alcohol abuse, refractory ascites (as defined by requiring paracentesis more than twice within the prior month), prior placement of a portosystemic shunt, current or historical portal vein thrombosis, active variceal bleeding within the prior 6 months; expected survival of less than 1 year, oesophygeal varices with risky sign, on non-selective $\beta$-blockers, history of clinically significant medical condition associated with other chronic liver disease, severe hepatic impairment, history of hepatorenal or hepatopulmonary syndrome, active spontaneous bacterial peritonitis or major laboratory disturbance like alphafetoprotein >100(unless the patient was negative for hepatic masses via imaging within the prior 3 months), haemoglobin $<8 \mathrm{~g} / \mathrm{dL}$, with neutrophils $<1000$ cells $/ \mathrm{mm} 3$, platelets $\leq 75000 / \mathrm{mm} 3$, creatinine $\geq 1.5 \times$ ULN or total bilirubin $>5$ $\mathrm{mg} / \mathrm{dL}$.

\section{Ethical Aspects:}

I. Approving protocol: Current protocol will be approved by Committee of Tropical Medicine Department and Committee of Faculty of Medicine at Al-Azhar university, and then by the ethical committee at Al-Azhar university.

II. Patient Consent: All patients that were included in current study signed approved consents.

\section{Statistical analysis:}

Statistical analysis was done using SPSS software, version 20.0 (SPSS Inc., Chicago, IL, USA). Continuous variables are expressed as mean and standard deviation while qualitative variables were expressed as frequencies. Paired Student's $t$ test is used for comparisons between preand post-treatment for normally distributed data and Wilcoxon matched pairs signed-rank test when not normally distributed. Simple linear regression was carried out to investigate the relationship between the change in liver stiffness and the change in laboratory values from Pretreatment to after treatment. Pearson correlation (r) test is used to measure the association between liver stiffness measurement and portal hemodynamics parameters. A 2-tailed 0.05 significance level has been used in all statistical tests. 


\section{RESULTS}

The current study included $70 \mathrm{HCV}$ cirrhotic patients, 56 of them were males $(80 \%)$ and 14 were females (20\%) aging 21-65 years old with a mean age of $55.71 \pm 8.97$ years. Pre-treatment characteristics showed LSM of all patients were F4 included with Fibro Scan score mean 26.32 $\pm 10.23 \mathrm{Kpa}$. Baseline fasting blood glucose (FBG) mean value was $103.61 \pm 15.37 \mathrm{mg} / \mathrm{dl}$ and alfa feto protein (AFP) mean value was $16.87 \pm 23.82$ $\mathrm{ng} / \mathrm{ml}$. Ultrasound examination as pretreatment assessment showed the percent of patients having cirrhotic, coarse and non-cirrhotic liver were $74.3 \%, 22.8 \%$ and
2.9\% respectively, spleen : $64.3 \%$ had splenomegaly while $35.7 \%$ of the patients had normal spleen. None of the patients had ascites or hepatic focal lesions. Liver stiffness of all patients was F4 included with fibro scan score mean $26.32 \pm 10.23$ kilo Pascal's (Kpa). Sixty one patients $(87.1 \%)$ hadn't received any previous treatment while only 9 patients $(12.9 \%)$ experienced previous treatment. The treatment protocols applied were: Sofosbuvir+ Daclatasvir or Simprevir \pm Ribavirin. Fifty nine patients $(84.3 \%)$ were treated for 12 weeks and 11 patients (15.7\%) for 24 weeks (Table 1). 
Table (1): Baseline characteristics of the patients

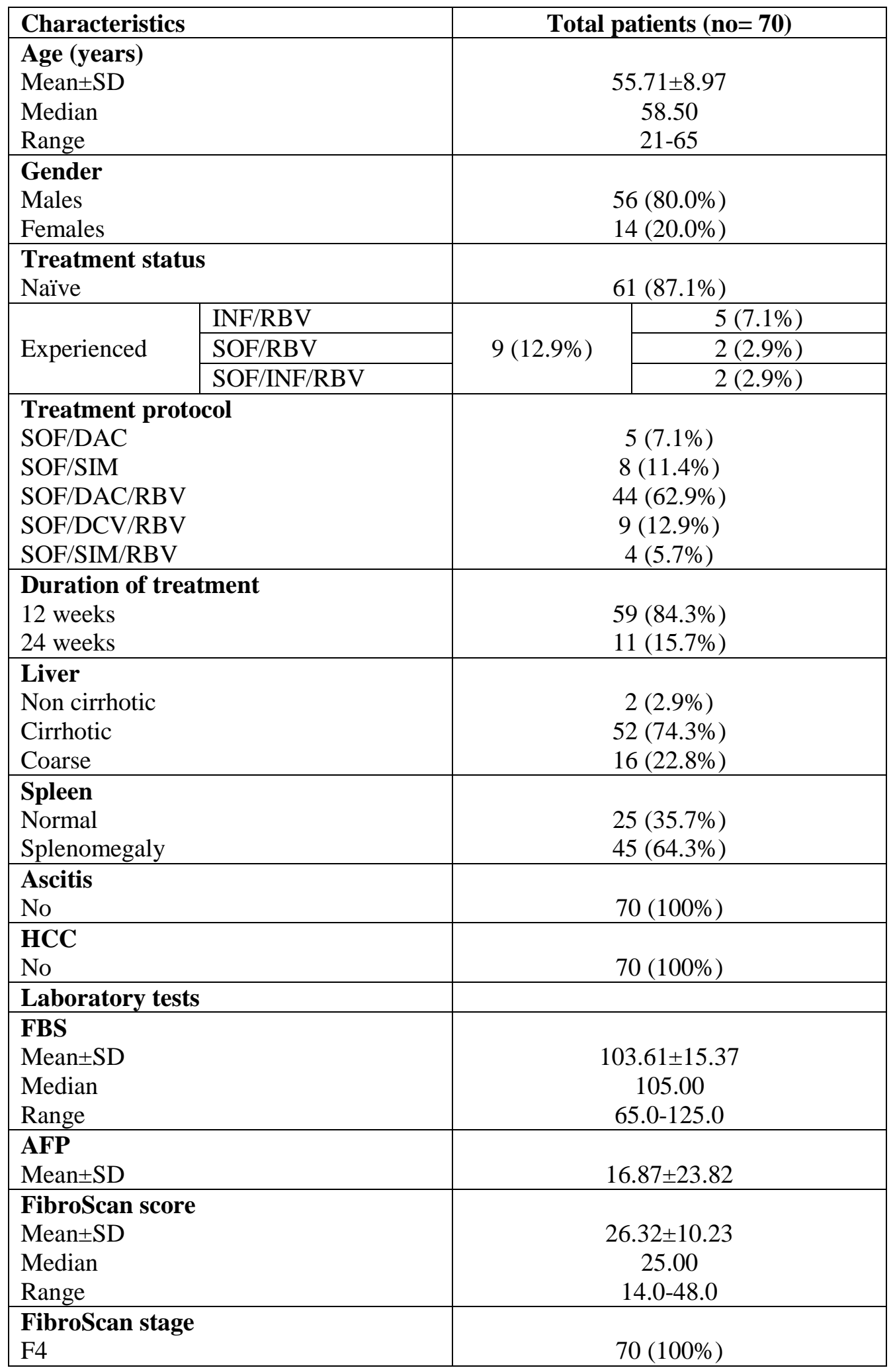


Immediately after EOT, both Total and Direct Bilirubin significantly increased. AST and ALT significantly improved. Both Hemoglobin and Platelets showed significant decreased ( $\mathrm{P}$-value $<0.001$ for all parameters). Serum Albumin, WBCs, INR and Serum Creatinine showed nonsignificant change (Table 2).

Table (2): Clinical laboratory values pre-treatment and immediately at the end of treatment

\begin{tabular}{|l|c|c|c|c|}
\hline Parameters & $\begin{array}{c}\text { Pre- } \\
\text { treatment }\end{array}$ & $\begin{array}{c}\text { immediately at the } \\
\text { end of treatment }\end{array}$ & Change & P -value \\
\hline Total bilirubin(mg/dl) & $1.02 \pm 0.43$ & $1.49 \pm 0.68$ & -3.92 & $<0.001$ \\
\hline $\begin{array}{l}\text { Direct bilirubin } \\
(\mathrm{mg} / \mathrm{dl})\end{array}$ & $0.40 \pm 0.23$ & $0.77 \pm 0.56$ & 0.37 & $<0.001$ \\
\hline Albumin $(\mathrm{g} / \mathrm{dl})$ & $4.75 \pm 0.93$ & $3.48 \pm 0.55$ & -1.26 & 0.07 \\
\hline $\begin{array}{l}\text { Aspartate } \\
\text { Aminotransferase } \\
(\text { AST) }(\mathrm{U} / \mathrm{L})\end{array}$ & $76.38 \pm 51.14$ & $46.67 \pm 27.18$ & -29.71 & $<0.001$ \\
\hline $\begin{array}{l}\text { Alanine } \\
\text { Aminotransferase } \\
(\text { ALT) }(\mathrm{U} / \mathrm{L})\end{array}$ & $77.27 \pm 56.81$ & $47.52 \pm 24.93$ & -29.75 & $<0.001$ \\
\hline INR & $1.21 \pm 0.15$ & $1.2 \pm 0.17$ & 0.002 & 0.85 \\
\hline Creatinine $(\mathrm{mg} / \mathrm{dl})$ & $0.87 \pm 0.17$ & $0.88 \pm 0.29$ & -1.51 & 0.82 \\
\hline Hemoglobin $(\mathrm{g} / \mathrm{dl})$ & $12.92 \pm 2.19$ & $11.41 \pm 1.76$ & 0.36 & $<0.001$ \\
\hline WBCs $(\times \mathbf{1 0 0 0})$ & $6.05 \pm 2.05$ & $6.41 \pm 2.25$ & 0.009 & 0.13 \\
\hline Platelets $(\times \mathbf{1 0 0 0})$ & $136.6 \pm 52.65$ & $129.25 \pm 51.05$ & -7.34 & $<0.001$ \\
\hline
\end{tabular}

*Wilcoxon signed ranks test

One year after EOT, both total and direct bilirubin significantly increased (Pvalue $0.01,0.001$ respectively). AST, ALT and LSM significantly improved. Both Hemoglobin and Platelets showed significant decreased ( $\mathrm{P}$-value $<0.001$ for all parameters). Serum albumin, WBCs, INR and serum creatinine showed an insignificant change (Table 3).

Table (3): Clinical laboratory values pre-treatment and one year after the end of treatment

\begin{tabular}{|c|c|c|c|c|}
\hline $\begin{array}{ll}\text { Parameters } & \text { Variables } \\
\end{array}$ & Pre-treatment & $\begin{array}{l}\text { one year after the } \\
\text { end of treatment }\end{array}$ & Change & $P$-value \\
\hline $\begin{array}{l}\text { Total bilirubin } \\
(\mathrm{mg} / \mathrm{dl})\end{array}$ & $1.02 \pm 0.43$ & $1.47 \pm 1.38$ & $0.45 \pm 1.46$ & 0.01 \\
\hline Direct bilirubinn $(\mathrm{mg} / \mathrm{dl})$ & $0.40 \pm 0.23$ & $0.73 \pm 0.79$ & $0.33 \pm 0.79$ & 0.001 \\
\hline Albumin $(\mathrm{g} / \mathrm{dl})$ & $4.75 \pm 5.93$ & $3.54 \pm 0.59$ & $-1.21 \pm 5.92$ & 0.09 \\
\hline $\mathbf{A S T}(\mathrm{U} / \mathrm{L})$ & $76.38 \pm 51.14$ & $37.17 \pm 21.54$ & $-39.21 \pm 37.02$ & $<0.001$ \\
\hline ALT(U/L) & $77.27 \pm 56.81$ & $30.30 \pm 19.41$ & $-46.97 \pm 45.81$ & $<0.001$ \\
\hline INR & $1.21 \pm 0.15$ & $1.20 \pm 0.14$ & $-0.006 \pm 0.16$ & 0.74 \\
\hline Creatinine (mg/dl) & $0.87 \pm 0.17$ & $0.77 \pm 0.26$ & $-0.10 \pm 0.29$ & 0.006 \\
\hline Hemoglobin(g/dl) & $12.92 \pm 2.19$ & $11.54 \pm 1.66$ & $-1.37 \pm 1.24$ & $<0.001$ \\
\hline WBCs $(\times 1000)$ & $6.05 \pm 2.05$ & $6.62 \pm 1.83$ & $0.57 \pm 2.6$ & 0.07 \\
\hline Platelets $(\times 1000)$ & $136.6 \pm 52.65$ & $125.44 \pm 49.48$ & $-11.16 \pm 14.23$ & $<0.001$ \\
\hline $\begin{array}{l}\text { Liver stiffness } \\
\text { measurement }(\mathrm{Kpa})\end{array}$ & $26.32 \pm 10.23$ & $19.89 \pm 8.25$ & $-6.44 \pm 6.11$ & $<0.001$ \\
\hline
\end{tabular}

*Wilcoxon signed ranks test 
All patients were Fibroscan stage F4 $(100 \%)$ at the pre-treatment examination and on examination 1 year after EOT
LSM significantly improved to F2 $(2.9 \%)$, F3 (17.1\%), F4 (80.0\%) (P-value 0.01) (Table 4).

Table (4): Change in Liver Stiffness from Pre-treatment to after treatment

\begin{tabular}{|c|c|c|c|c|}
\hline \multicolumn{2}{|c|}{$\begin{array}{ll}\text { Parameters } & \text { Variables } \\
\end{array}$} & Pre-treatment & After-treatment & $P$ value \\
\hline \multirow{2}{*}{ F2 } & No $(\%)$ & $0(0 \%)$ & $2(2.9 \%)$ & \multirow[b]{2}{*}{---------- } \\
\hline & Mean \pm SD & --------- & $8.80 \pm 0.01$ & \\
\hline \multirow{2}{*}{ F3 } & No $(\%)$ & $\mathbf{0}(\mathbf{0 \%})$ & $12(17.1 \%)$ & \\
\hline & Mean \pm SD & -------- & $11.33 \pm 0.94$ & \\
\hline \multirow{2}{*}{ F4 } & No $(\%)$ & $70(100.0 \%)$ & $56(80.0 \%)$ & \multirow[b]{2}{*}{0.01} \\
\hline & Mean \pm SD & $26.32 \pm 10.23$ & $19.89 \pm 8.25$ & \\
\hline
\end{tabular}

One year after EOT doppler parameters included PV diameter, PVV, CI, LVI and HARI significantly improved (P-value
$<0.001$ for all parameters except HARI 0.001). Both PVF and HAPI showed insignificant change (Table 5).

Table (5): Comparison of Pre-treatment and one year after the end of treatment regarding portal vein hemodynamics

\begin{tabular}{|l|c|c|c|c|}
\hline Variables & Pre-treatment & $\begin{array}{c}\text { one year after the } \\
\text { end of treatment }\end{array}$ & Change & $\begin{array}{c}\text { P - } \\
\text { value }\end{array}$ \\
\hline PV diameter(mm) & $12.76 \pm 0.97$ & $11.84 \pm 1.06$ & -0.92 & $<0.001$ \\
\hline PV velocity (cm / sec) & $15.43 \pm 1.24$ & $16.12 \pm 1.64$ & 0.69 & $<0.001$ \\
\hline PV flow rate (mL/ sec) & $1285.53 \pm 41.93$ & $1289.34 \pm 41.47$ & 3.81 & 0.47 \\
\hline $\begin{array}{l}\text { Congestion index of portal } \\
\text { vein (cm x sec) (CI) }\end{array}$ & $0.09 \pm 0.01$ & $0.08 \pm 0.01$ & -0.007 & $<0.001$ \\
\hline $\begin{array}{l}\text { Pulsatility index of Hepatic } \\
\text { artery (HAPI) }\end{array}$ & $1.10 \pm 0.08$ & $1.09 \pm 0.22$ & -0.008 & 0.73 \\
\hline $\begin{array}{l}\text { Resistive index of Hepatic } \\
\text { artery (HARI) }\end{array}$ & $0.66 \pm 0.05$ & $0.63 \pm 0.07$ & -0.03 & 0.001 \\
\hline Liver vascular index (LVI) & $14.07 \pm 1.42$ & $15.21 \pm 2.98$ & 1.13 & $<0.001$ \\
\hline
\end{tabular}

\section{DISCUSSION}

Our study included 70 cirrhotic patients. After 3 months and 1year of EOT, sustained viral response was achieved. Concerning total and direct bilirubin, both significantly increased at EOT and 1 year after EOT which is in contradiction to Mahmoud et al. (2017) and Elsayed et al. (2019).

For serum albumin, at EOT decreased insignificantly, while one year after EOT it increased insignificantly which was in agreement with Chekuri et al. (2016), Mahmoud et al. (2017) and Elsayed et al. (2019) who reported a significant increase of serum albumin after treatment $(\mathrm{p}<0.03)$.

As regard to AST and ALT, both significantly decreased at EOT and one year after EOT. This was in agreement with Chekuri et al. (2016), Mahmoud et al. (2017), Puente et al. (2017), Elsayed et al. (2019), Mansour et al. (2019) and Ezzelregal et al. (2020) who reported a 
significant decrease of AST and ALT levels after treatment.

Concerning creatinine level, an insignificant change was reported at EOT and 1 year after EOT unlike Elsayed et al. (2019). For international ratio (INR), an insignificant change was reported at EOT and 1 year after EOT. Mahmoud et al. (2017) and Elsayed et al. (2019) reported a decrease in prothrombin time.

For hemoglobin ( $\mathrm{Hb})$ level, it significantly decreased at EOT and 1 year after EOT. This was in agreement with Mahmoud et al. (2017), Puente et al. (2017), Elsayed et al. (2019), Mansour et al. (2019) and Ezzelregal et al. (2020), while Chekuri et al. (2016) stated that the difference was not significant.

As regard to white blood count (WBCs), it insignificantly changed at EOT and 1 year after EOT. This was in agreement with Elsayed et al. (2019), but in contradiction to Mansour et al. (2019) who reported a decrease in WBCs count after treatment. This could be due to use of ribavirin. For platelets count, it significantly decreased at EOT and 1 year after EOT, which was in agreement with Puente et al. (2017) but in contradiction to Chekuri et al. (2016), Mahmoud et al. (2017), Elsayed et al. (2019), Mansour et al. (2019) and Ezzelregal et al. (2020) due to including of ribavirin in therapeutic regimens of most patients.

The significant decrease of LS measurement was in agreement with Chekuri et al. (2016), Dolmazashvili et al. (2017), Grgurevic et al. (2017), Mahmoud et al. (2017), Puente et al. (2017), Mansour et al. (2019) and Ezzelregal et al. (2020).
Congestion index was in agreement with Achim et al. (2016). For hepatic artery Doppler assessment: HAPI was in agreement with Achim et al. (2016). Ahmed and Medhat (2019) reported that the mean of HARI was relatively equal in Child A and Child B. Concerning liver vascular index (LVI), it was in agreement with Achim et al. (2016).

For the comparison between pretreatment and 1year after EOT Doppler assessment, pre-treatment portal vein (PV) diameter significantly decreased, velocity (PVV) was significantly improved which was in agreement with Mahmoud et al. (2017) who reported that the PVV significantly improved at EOT in addition to a significant improvement on week 24. In addition, Elsayed et al. (2019) stated that PVV improved.

In a study by Akhter et al. (2012), the mean PVV after 2 weeks of therapy significantly increased as compare to preIFN. However, after 24 weeks of therapy, there was no significant difference in the portal blood flow velocity.

As regard to the portal vein flow rate, it improved in agreement with Mahmoud et al. (2017) who reported that the flow rate was significantly increased at EOT and on week 24. Also, Elsayed et al. (2019) stated that flow rate significantly improved.

For congestion index, it significantly changed in agreement with Mahmoud et al. (2017) who reported a significant increase in CI at EOT and on week 24. Furthermore, Elsayed et al. (2019) stated that CI, as well, showed significant improvement. 
Concerning the hepatic artery, it showed that HAPI decreased while resistive index (RI) significantly decreased which was in agreement with Elsayed et al. (2019) who stated that HARI significantly improved.

For liver vascular index, it significantly changed. Mahmoud et al. (2014) found that LVI showed statistically significantly lower values in patients with OVs than those without OVs.

\section{CONCLUSION}

Eradication of $\mathrm{HCV}$ infection with new DAAs was associated with significant improvement in portal circulation hemodynamics such as PVV, CI, HARI and LVI in correlation with significant decrease in LVM, ALT and AST.

Conflict of interest: All Authors declared that no conflict of interest and no financial support from any agency.

Acknowledgement: The authors are grateful for the patients without whom this study would not have been done.

\section{REFERENCES}

1. Achim, CA., Bordei, P. and Dumitru, E. (2016): The role of ultrasonography in the evaluation of portal hemodynamics in healthy adults and pathologic conditions. ARS Medica Tomitana. 22(2):128-34.

2. Ahmad, M. and Medhat, I. (2019): Doppler Ultrasound of Hepatic Artery and Portal Vein: Relationship with Clinical Severity of Hepatitis C Virus Liver Cirrhosis. The Medical Journal of Cairo University. 87:3589-95.

3. Akhter, S., Amin, S. and Daula, MI. (2012): Changes in portal vein hemodynamics evaluated by duplex ultrasound in chronic hepatitis C patients treated with interferon and ribavirin. Rawal Medical Journal. 37(4):390-4.
4. Castéra L, Vergniol J, Foucher J, Le Bail B, Chanteloup E, Haaser M, Darriet M, Couzigou $P$, and de Lédinghen $V$ (2005): Prospective comparison of transient elastography, Fibrotest, APRI, and liver biopsy for the assessment of fibrosis in chronic hepatitis C. Gastroenterology. 128(2):343-50.

5. Charlton M, Everson GT, Flamm SL, Kumar P, Landis C, Brown Jr RS, Fried MW, Terrault NA, O'Leary JG, Vargas HE, Kuo A (2015): Ledipasvir and sofosbuvir plus ribavirin for treatment of HCV infection in patients with advanced liver disease. Gastroenterology. 149(3):64959.

6. Chekuri S, Nickerson J, Bichoupan K, Sefcik R, Doobay K, Chang S, DelBello D, Harty A, Dieterich DT, Perumalswami PV, Branch AD (2016): Liver stiffness decreases rapidly in response to successful hepatitis $\mathrm{C}$ treatment and then plateaus. PLoS One. 11(7):e0159413.

7. Dolmazashvili E, Abutidze A, Chkhartishvili N, Karchava M, Sharvadze $\mathrm{L}$ and Tsertsvadze T (2017): Regression of liver fibrosis over a 24-week period after completing direct-acting antiviral therapy in patients with chronic hepatitis $\mathrm{C}$ receiving care within the national hepatitis $\mathrm{C}$ elimination program in Georgia: results of hepatology clinic HEPA experience. European Journal of Gastroenterology \& Hepatology. 29(11):1223-30.

8. Elsayed MA, Ibrahim, IM and Amer, KA (2019): Insulin resistance and portal heamodynamics changes before and after treatment by new direct antivirals drugs in chronic HCV. Afro-Egyptian Journal of Infectious and Endemic Diseases. 9(2):150-7.

9. Ezzelregal, IA, Elraie, FM, Elmolla, KA and Shaqueer, MM (2020): Effect of Successful Direct Acting Antivirals Therapy on Liver Stiffness in Patients with Chronic HCV Infection. International Journal of Medical Arts. 2(4):854-859.

10. Grgurevic I, Bozin T, and Madir A (2017): Hepatitis $\mathrm{C}$ is now curable, but what happens with cirrhosis and portal hypertension 
afterwards?. Clinical and experimental hepatology. 3(4):181.

11. Hézode C, Fontaine H, Dorival C, Zoulim F, Larrey D, Canva V, De Ledinghen V, Poynard T, Samuel D, Bourlière M, Alric L (2014): Effectiveness of telaprevir or boceprevir in treatment-experienced patients with HCV genotype 1 infection and cirrhosis. Gastroenterology. 147(1):132-42.

12. Hsieh YC, Lee KC, Wang YW, Yang YY, Hou MC, Huo TI and Lin HC (2018): Correlation and prognostic accuracy between noninvasive liver fibrosismarkers and portal pressure in cirrhosis: Role of ALBI score. PLoS One. 13(12):e0208903.

13. Kayacetin, E, Efe, D and Doğan, C (2004): Portal and splenic hemodynamics in cirrhotic patients: relationship between esophageal variceal bleeding and the severity of hepatic failure. Journal of gastroenterology. 39(7):661-7.

14. Mahmoud HS, Mostafa EF and Mohammed MA (2014): Role of portal haemodynamic parameters in prediction of oesophageal varices in cirrhotic patients. Arab Journal of Gastroenterology. 15(34):130-4.

15. Mahmoud H, Osman H, Abdelrazek $G$ and Al-Senbesy M (2017): Evaluation of Portal Hypertension Doppler Parameters after Hepatitis C Virus Eradication in Patients with Definite Fibrosis. Int. J. Curr. Res. Med. Sci. 3(11):46-54.

16. Mandorfer M, Kozbial $K$, Freissmuth $C$, Schwabl P, Stättermayer AF, Reiberger T, Beinhardt S, Schwarzer R, Trauner M, Ferlitsch $A$ and Hofer $H$ (2015): Interferonfree regimens for chronic hepatitis $\mathrm{C}$ overcome the effects of portal hypertension on virological responses. Alimentary pharmacology \& therapeutics. 42(6):707-18.

17. Manns M, Samuel D, Gane EJ, Mutimer D, McCaughan G, Buti M, Prieto M, Calleja JL, Peck-Radosavljevic M, Müllhaupt B and Agarwal K (2016): Ledipasvir and sofosbuvir plus ribavirin in patients with genotype 1 or 4 hepatitis $\mathrm{C}$ virus infection and advanced liver disease: a multicentre, open-label, randomised, phase 2 trial. The Lancet Infectious Diseases. 16(6):685-97.

18. Mansour RH, Zaky S, El Kassas M, Mamdouh $H$ and Esmat $G$ (2019): Evaluating the effect of direct-acting agents on liver fibrosis, by real-time elastography, Fibroscan and FIB4 score in chronic HCV patients. The Scientific Journal of Al-Azhar Medical Faculty, Girls. 3(1):237.

19. Møller S. and Henriksen JH. (2010): Cirrhotic cardiomyopathy. Journal of hepatology. 53(1):179-90.

20. Pinzani M (2015): Liver fibrosis in the post$\mathrm{HCV}$ era. InSeminars in liver disease. Thieme Medical Publishers. 35)2(:157-165.

21. Puente Á, Cabezas J, López Arias MJ, Fortea JI, Arias MT, Estébanez Á, Casafont F, Fábrega $\mathbf{E}$ and Crespo J (2017): Influence of sustained viral response on the regression of fibrosis and portal hypertension in cirrhotic $\mathrm{HCV}$ patients treated with antiviral triple therapy. Revista Española de Enfermedades Digestivas. 109(1):17-25.

22. Reiberger T, Rutter $K$, Ferlitsch A, Payer BA, Hofer H, Beinhardt S, Kundi M, Ferenci P, Gangl A, Trauner $M$ and PeckRadosavljevic M (2011): Portal pressure predicts outcome and safety of antiviral therapy in cirrhotic patients with hepatitis $\mathrm{C}$ virus infection. Clinical Gastroenterology and Hepatology. 9(7):602-8.

23. Soresi M, Giannitrapani L, Cervello $M$, Licata A and Montalto G (2014): Non invasive tools for the diagnosis of liver cirrhosis. World journal of gastroenterology: WJG. 20(48):18131.

24. Tsochatzis EA, Bosch J and Burroughs AK (2014): Liver cirrhosis. The Lancet. 383(9930):1749-61. 
تأثثير علاج فيروس سي بالمضادات الفيروسية المباشرة علي الدورة البابية في مرضي بالي التليف الكبدي

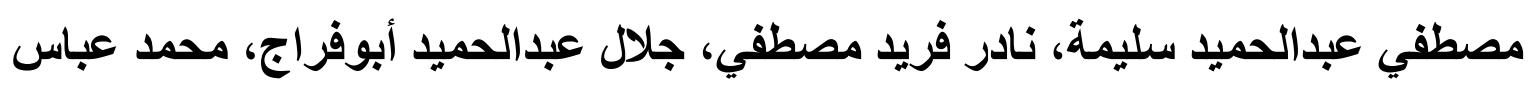
ضيف

قسم أمراض الكبد والجهاز الهضمى والأمراض المعدية، كلية الطب، جامعة الأزهر

قسم الأثعة التداخلية معهد الكبد القومي شبين الكوم المنوفية

E-mail: $\underline{\text { mostselima@gmail.com }}$

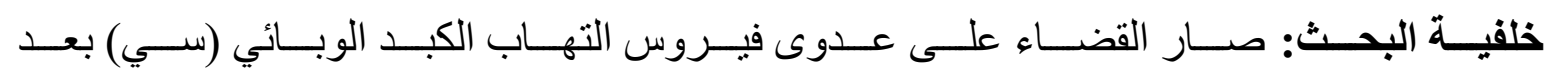

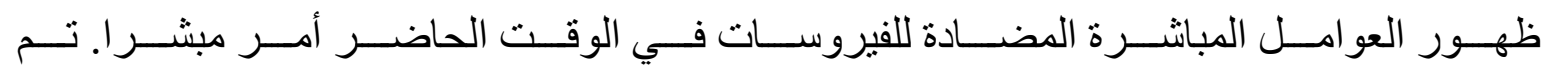

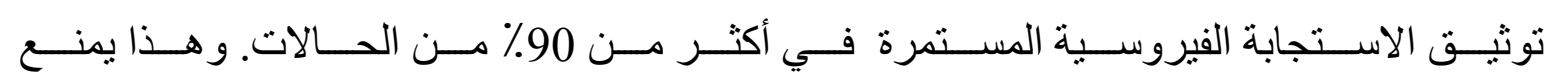

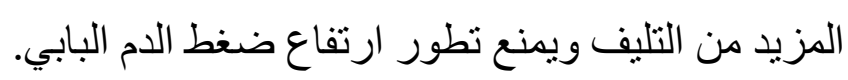

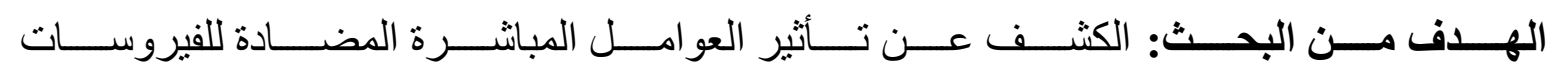

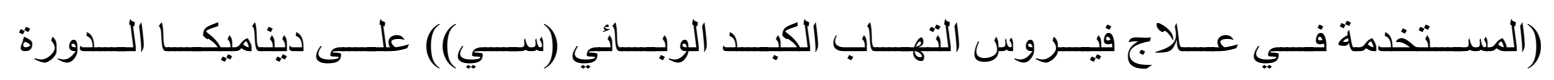
الدموية في الوريد البابي.

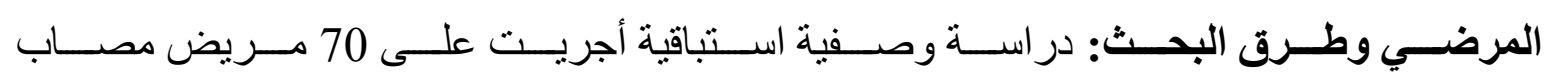

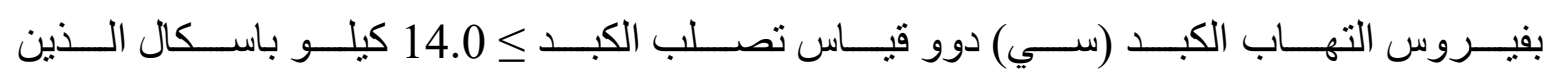

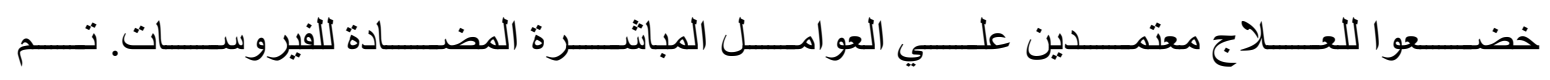

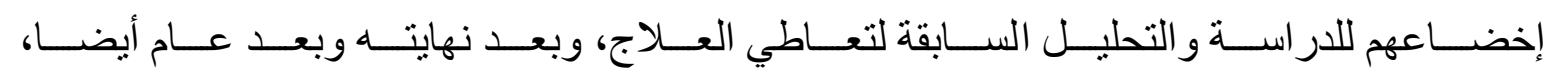

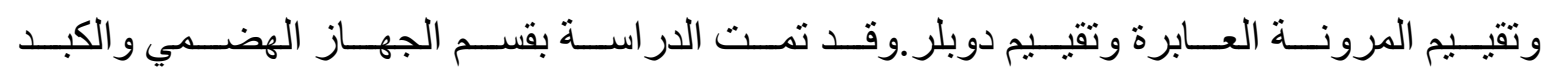

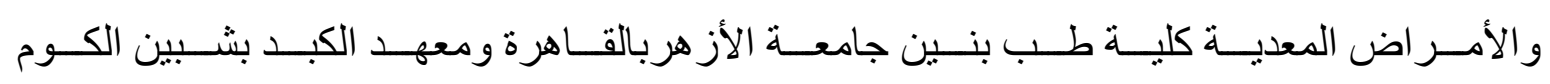
جامعة المنوفية خلال الفترة من مايو 2018 إلي ديسمبر 2019.

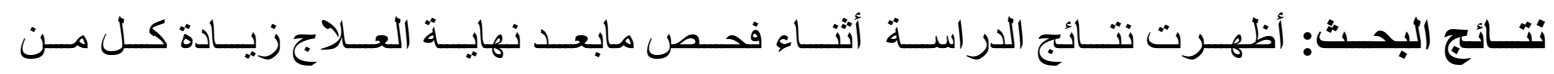

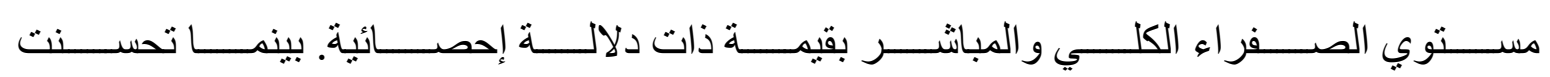

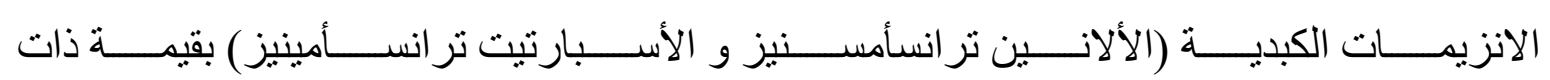

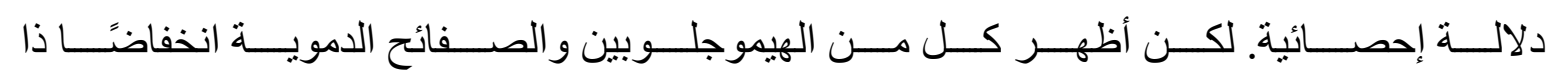




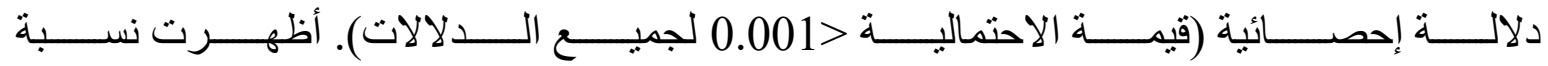

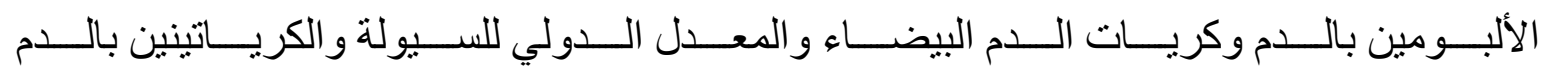
تغيرًا طفيفًا.

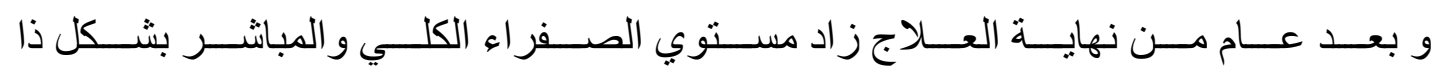

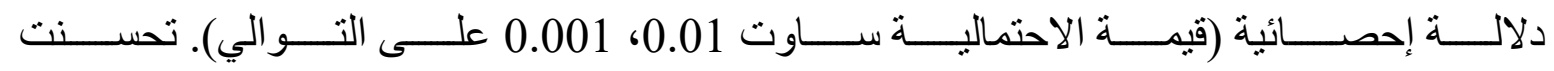

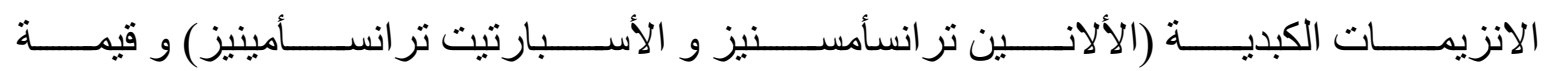

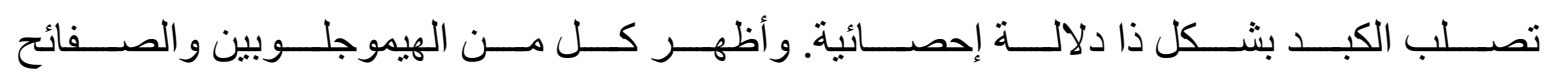

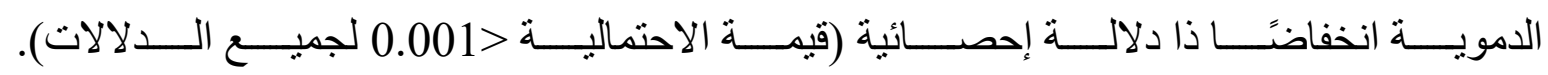

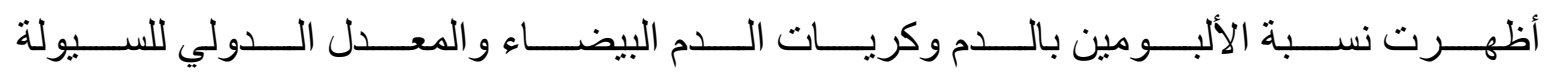
و الكرياتينين بالدم تغيرًا طفيفًا.

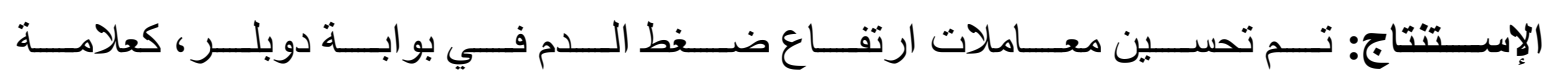

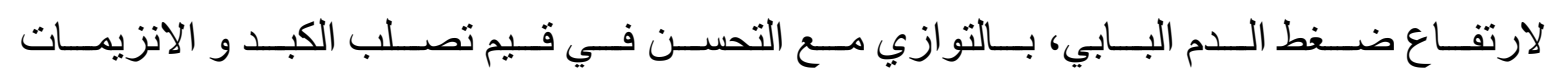
الكبدية (الألانين تر انسأمسنيز و الأسبارتيت ثر انسأمينيز) بعد استئصال الفيروس.

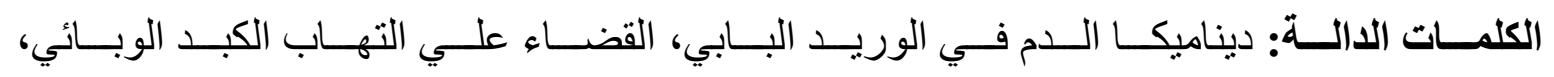

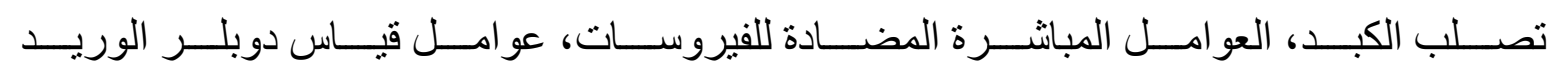
البابي. 